\title{
SOURCES OF ENVIRONMENTAL HAZARDS EFFECTS AND CONTROL
}

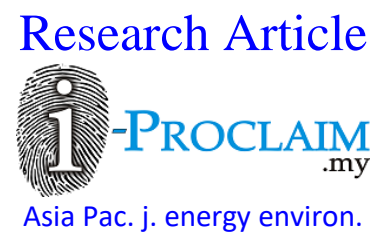

\section{Abdulraheem Mukhtar Iderawumi}

Department of Agricultural Education, The College of Education, P.M.B. 001, Lanlate, Oyo State, NIGERIA

*Email for Correspondence: m.iderawumi@gmail.com

Abstract

The entire world become village and whatever affects a country will ultimately affect the neighbouring ones. Since the environment is being constantly polluted by man through its various activities such an acts constitutes hazard to man and its ecological being and a threat to public health. An environmental hazard is a substance, state or event which has the potential to threaten the surrounding natural environment and / or adversely affect people's health. This term incorporates topics like pollution and natural disasters such as storms and earthquakes. Human-made hazards while not immediately health-threatening may turn out detrimental to man's well-being eventually, because deterioration in the environment can produce secondary, unwanted negative effects on the human ecosphere. The effects of water pollution may not be immediately visible because of a sewage system that helps drain off toxic substances. If those substances turn out to be persistent (e.g. persistent organic pollutant), however, they will literally be fed back to their producers via the food chain: plankton -> edible fish -> humans. In that respect, a considerable number of environmental hazards are man-made (anthropogenic) hazards. This necessitate to this study of investigating, the sources, effects and controls of environment hazards. Data were gathered from Primary Health Care (P.H.C) department and from environment department through oral interview method. The findings from the data collected revealed that's the people in the study area have negative attitude towards environmental hazards which make them to mismanage environmental resources such as land, water and air. Investigation also shows that, there were poor and inadequate system of refuse disposition and that the system most of the houses in the area are without adequate toilet facilities. Health education should be given to the people on the sources and effects of environmental hazards. It is therefore hoped that, if the recommendation made in this study is staffs strictly adhered to, it would go a long way in improving the environmental condition.

Key words

Health, Hazard, Malaria, Environmental, Farming

This article is is licensed under a Creative Commons Attribution-NonCommercial 4.0 International License.

Attribution-Non Commercial (CC BY-NC) license lets others remix, tweak, and build upon work non-commercially, and although the new works must also

acknowledge \& be non-commercial.

\section{INTRODUCTION}

Environmental factors can of course kill efforts to develop previously-used urban property, however, this study demonstrates that the underlying economics of a deal and other factors not directly-related to the threat of contamination are ultimately more important to the feasibility of brownfield redevelopment. Most deals worth doing will not be fatally harmed by environmental contamination or liability concerns. Only recently many people realized that the environment must be carefully managed and protected from destruction and further harm. The rapid increase in human population, increase urbanization and overcoming in some parts of the country have made it difficult to supply everyone with the essentials of life. The spread of vast and often ugly cities with their transport system is changing the country's environment and damaging plants animals and property. This incidents fire disaster from petrol/kerosene explosion killing hundred and leaving other disabled and homeless and the most various recent bomb blasts with thousand dead and many others rendered homeless are till fresh in our memories. To this end, it is hoped that intensive efforts directed at HIV/AIDS related hazards will be liven to other environmental hazards, some of which even terminate lives faster or leaves survivors with permanent disabilities, 
thus if the life expectancy must improve in Nigeria, our environment, must be given a better attention and to a greater extent rid of those hazards with are life threatening.

"Health is Wealth" as usually said by people. But the erotically health can be defined as the ability to function effectively in complete harmony with one's environment i.e. health is a merely the absence of infirmity by World Health Organization (WHO).

Environment as defined in the Oxford Advanced Learner's Dictionary implies condition, circumstance affecting a person's life (positively or negatively) as the aggregate of external conditions and influences affecting life and development of either a man or an animals or an organism. It includes atmosphere and the air we breather. The water we drink and the land/soil in which crops are grown.

Man himself has set in motion forces of such magnitude and rapidity as to challenge seriously his own adaptive. It is to his adaptive ability of man that attention is directed. So also, the world human population continue to multiply means influence upon his environment become more intense each year some of the ways by which human influence his environment is through the use of chemical which leads to pollutions of various form pollution when occur when something is rendered unfit for a certain purpose for instance a cup of milk is polluted when a few drops of kerosene is added to it since it cannot be taken and is considered dangerous

Apart from deficiencies in the life support system, man is subjected to a variety of hazard resulting from environmental pollution. Some of this are natural, but increasingly environment hazards result from man's activities and sometimes, man may indirect influence acting through other biological systems. This interference by the man can be seen in the use of chemical affect the natural of plants and animals in the area and which in the have proved to be harmful man himself. Industrialization, in many countries is now creating a great problem for man inform of pollution has adverse effects to plant and animal in the communities.

This goes forth to show the significance of environment in which human beings as well as survival of all living things depends on three vital phenomena i.e. air, water and soil which incidentally often get polluted or contaminated through various hazards for normal growth and development right from childhood, a conductive environment is essential.

Hazard means, a things that can be dangerous or cause damage. According to Sofoluwe (1971) Hazard is regarded as a danger or a risk, which may pose a serious threat to life. Anything that constitutes a problem within the environment can be referred to as hazard. For instance if a few drop of kerosene is mixed with water and if man take it. According, to Ajani (1987) environmental hazard can be defined as any materials or substance introduced into the environment that cause damage to people and all thing present there.

Oyo State environmental protection Agency sees Environmental hazard to be factors or situation generated with the environment which may be injurious in health and constituting threat to the survival of human being and other living beings. The list of hazards to which human being are exposed resulting in environment pollution is inexhaustible.

Environmental pollution consists of all forms of pollution that take place within and neighboring of an organism. But it is now used in a more special sense. All living things are influenced to an enormous extent by their surrounding and the large number of circumstances, which may have their good or bad effects on the organism are grouped together as their environmental.

Bad farming methods and techniques combined with erosion and deforestation have made desorts of once fertile regions. The introduction of certain types of animals into areas where they were previously unknown has upset the natural ecosystem cause problems of pest control, dumping of waste into rivers and stirrup, poisonous gases from factories, motor car, exhausts and noise from air craft engines are among the causes of pollution to our environment. It is very important to indicate that livings including man are able to adapt to change as may be reflected from the course of evolution. However just as the environment changes with passing occurrences and events human beings have been able to adjust to many different environments (But at what cost) many have found ways of controlling or adapting to the environment.

\section{SOURCES OF ENVIRONMENTAL HAZARDS}

At the beginning the environment was said to be clean and free from pollutions. The early man constitutes threat on this surrounding because of his low level technology. However, as a result of man's activities on earth such as domestic, commercial, industrial or agricultural, the environmental becomes polluted, dirty, and unsightly and serving as potential sources of infection coupled with this technology advancement and rapid urbanization which brings about development such as establishment of markets, industries, small or large scale prospects, such as economic advancement longevity etc. and problems such as filthy drain, accumulation of refuse, odour etc. It 
becomes imperative that steps must be taken to rid the environment of these filthy situation in order to promote healthy living and longevity and as well maintain aesthetic value of environment.

According to Ajani (1987) he grouped sources of environment hazards into two namely, Pollution of various forms and diseases. He went further to grouped pollution into (4) four classes

Physical Pollution: - Physical pollution includes dusts, humidity, radiation, pressure, light and noise absolute dust among others are dangerous to health and causes cancer of various forms and other respiratory diseases.

Chemical Pollution: - Chemical pollution are the constituents of any substance that is any organism both living and non-living chemical pollution is not new to man. But the knowledge about the impact has until recently. Not been well understand. Among the toxic (dangerous) chemical encouraged through breathing are lead, carbon-monoxides, sulphur (IV) oxide and oxide of Nitrogen.

Biological Pollution: - this is mainly concerned mainly with bodily discharges in relation to communicable diseases: communicable are the types of diseases that can spread within very short time. Such as cholera. As man engages in activities association with living wastes are produced e.g. domestic sewage and agriculture wastes. In a community where such wastes products are not properly disposed, communicable disease will be rampant.

Psychological Pollution: - Although, the psychological and sociological parameters of environmental design are not as well pronounced as biological, chemical and physical factors, there is enough information to suggest that it is an area of serious concerns.

Interaction lack of open space, stress form work, traffic congestion and crowds, and estrangement from the conditions and crowds natured cycles under which human evolution take place are environment factors, which have been identified as having possible psychological and social consequences.

Environment pollution were further categorized as:

Land Pollution: - Land can be polluted by man or animal through their wastes products and though the activities of man e.g. through feaces or industrial waste e.g. saw mill. This cause unpleasant odour and it's destroy aesthetic beauty of the environment.

Water Pollution: - Water can be polluted through the activities of man and animals e.g. the faces been generated by man, when it rain it will be mashed into the over and as a result of that, polluted the water, then through domestic activities e.g. bathing, washing into the river or sources of water supply which make the water unwholesome for human consumption.

Air Pollution: - Air can be polluted through the activities of man. Through (Co) carbon monoxides been emitted into the air through vehicle. It cause fatigue in man and sleepless.

Ajani (1987) said that disease exists in various forms intensity having different symptoms. Incubating period and sign which can be group into two, communicable diseases and non-communicable diseases. Communicable diseases.

Rahimi etal. (2003) are otherwise known as "contagious" or "infectious" diseases which is an illness due to a specific infections agent or its toxic products from reservoir to susceptible host either directly from infected person or indirectly through the agent of intermediate animal or plant host a vector or in animate environment. It can also be defined as the diseases that can be that can be transferred from an infected or direct sources of animal to an healthy person through germs which are mostly found in dirty places where the atmosphere condition support their existence.

Different hazard have been affecting our environment and even man himself. So there is need for us to know the sources effects and with the knowledge we will be able take good care of our environment and ourselves.

\section{Material AND Methods}

There are various classification of hazards thus, they gain entrance through the mouth or cut(s) in the skin of their host causing diseases like malaria, cholera, typhoid fever etc. to prevent the attack of these diseases, water should be drawn from deep wells, spring or rain and should be boiled or add testified chemical to it before drinking. The storage unit should also be clean and covered always.

Typhoid fever occurs globally but most frequently in areas with poor sanitation. As late as 1909, there were up to 800,000 annual incidents of typhoid fever in the U.S.A. with over 40,000 deaths, the diseases was gradually controlled by filtration and chlorination of water supply but remains endemic in many other areas of the world. The agent Salmonellatyphis which cause typhoid fever is transmitted through water of food contaminated directly or indirectly with human feaces. 
CHOLERA is associate with dirty environment it is very serious abdominal diseases and during epidemics thousands die within few days. Chemoprophylams, mass treatment of community with antibiotics during an outbreak has never succeeded in limiting the spread of cholera.

VACCINATION: - Is of no practical value in cholera control during an epidemic since the currently available vaccines have been shown to provide only partial protection of short duration. Most importantly vaccination gives false sense of security to those vaccinated and to health authorities who may tend to neglect effective control measures.

Travel measures: - Since it is extremely difficult to isolate all infected persons during cholera outbreak as a number of them have no sign of illness, measures that restrict movement of people cannot prevent the spread of the disease.

MALARIA: - Of all the tropical disease, malaria is one of the most common. But due to the natural immunity that most common. But due to the natural immunity that most of the people in the area have not many die of it effects for many years, exporter from Europe to Africa and Asia died malaria. But with discovery of different drugs either prophylactics or cures, the mortality rate has been very much reduced. The diseased is not transmitted by vital population but on insect vector to which water is essential for maintenance of its aquatic larval life stage.

We could now see that all these diseases are caused by living in poor filthy environment but by living in conducive environment and near surrounding, the problem of environment will be solved. Such as physical hazard e.g. temperature, humidity, radiation etc.

\section{RESULtS AND Discussion}

Chemical hazards are defined in the Globally Harmonized System and in the European Union chemical regulations. They are caused by chemical substances causing significant damage to the environment. The label is particularly applicable towards substances with aquatic toxicity. An example is zinc oxide, a common paint pigment, which is extremely toxic to aquatic life.

Toxicity or other hazards do not imply an environmental hazard, because elimination by sunlight (photolysis), water (hydrolysis) or organisms (biological elimination) neutralizes many reactive or poisonous substances. Persistence towards these elimination mechanisms combined with toxicity gives the substance the ability to do damage in the long term. Also, the lack of immediate human toxicity does not mean the substance is environmentally nonhazardous. For example, tanker truck-sized spills of substances such as milk can cause a lot of damage in the local aquatic ecosystems: the added biological oxygen demand causes rapid eutrophication, leading to anoxic conditions in the water body.

All hazards in this category are mainly; anthropogenic although there exist a number of natural carcinogens and chemical elements like radon and lead may turn up in health-critical concentrations in the natural environment:

Rahimi, etal. (2003) communicable diseases can be classified into four major groups namely: water borne diseases, venereal diseases, insect borne diseases and Air borne diseases. But only water borne diseases will be discussed for this paper. Certain diseases causing organization are spread by drinking contaminated water and by walking in burning hydro-carbon fuel to generate motion power. During the process varying amounts of unwanted carbon dioxide (C02), hydrocarbon and nitrogen compounds are emitted.

Industrial sources also produces large number of pollutants like asbestos limestone, cement, fluorides gaseous pollutant e.g. sulphur oxide, carbon monoxides etc as experienced years back through improperly reined petrol and toxic wastes.

Nuclear Sources where biological weapon, virus, bacteria (Anthrax Energy sources). Noise is a form of energy transmitted through the air wastes of varying pressure - The main sources of noise are occupational activities like grinding, million (welding panel beating, block making etc.).

In a summary of report collected from a Primary Health Centre in Oyo state which covers four months i.e. January to April 2015, the statistical return is a regular monthly notification of three-selected disease (malaria, cholera and typhoid fever), because of their public wealth importance of which their incidence needs to be monitored.

In case of malaria for the month of January the data provided the effected of infected children between under 1 years to be $503,1-5$ years to be 473,5 to 14 years to be 371 and people above 15 years to be 402 , or the whole month 1749 years to the cases was recorded 20 death was recorded for the month of January.

For February, age under 1 years to be 586, people were infected for the age 15 and above 253 were infected, for the whole mouth 1531 were infected, no death was recorded. For March, under 1 years, 502 were infected; $1-4$ years 448 were infected 5 - 14, 448 were infected and age 15 and above 476 were infected. 
For April, under 1 years 233 cases were recorded, age 1-4 years 551, infected 5 - 14 years 374 were infected and age 15 and above 319 was recorded for the whole month 1677 were infected no death was recorded

In the case of cholera for month of January, under 1 year 16 cases was recorded, age 1-4, 28 cases was recorded, age 5-14, 43 was recorded for the whole 144 cases recorded, no death was recorded. For February, under 1 year 17 cases recorded, age 1-4, 13 cases was recorded, age 5-14 years, 32 cases was also recorded, age 15 and above 42 cases was recorded for the month 104 cases was recorded no death cases was recorded for the month of February. For March, under 1 years, 24 cases was recorded, age 1-4, 31 cases was recorded, 5-14, 31 cases was recorded, 15 and above 35 cases was recorded, for the whole month 121 cases was recorded no death was recorded. For April, under 1 years, 45 cases were recorded for age 1-4 years, 42 cases were recorded, for age 5-14 years, 40 cases were infected, age whole month 172 were infected no death was recorded in the cases of typhoid. There is no recorded that shows that is studying that data below carefully. It was found out that all the cases cholera is suspected cases.

Cholera is known to be epidemic diseases and a higher killer diseases. Therefore all preventive measures stated in chapter three of this diseases since prevention is better than cure. Also in the case of malaria diseases according to the data it is an endemic diseases which occur often in a community although according to the data does not affect very large people.

Table 1: Number of cases of malaria

\begin{tabular}{|c|c|c|c|c|c|c|c|c|c|c|c|c|c|c|c|}
\hline \multicolumn{4}{|c|}{ January } & \multicolumn{4}{|c|}{ February } & \multicolumn{4}{|c|}{ March } & \multicolumn{4}{|c|}{ April } \\
\hline $\begin{array}{c}\text { Under } \\
1 \mathrm{yr}\end{array}$ & $1-4$ & \begin{tabular}{|c|}
$5-14$ \\
yrs \\
\end{tabular} & $\begin{array}{l}15 \text { yrs } \\
\text { above }\end{array}$ & \begin{tabular}{|c|} 
Under \\
$1 \mathrm{yr}$ \\
\end{tabular} & 1-4 & $5-14$ & \begin{tabular}{|c|c}
15 \\
above
\end{tabular} & \begin{tabular}{|c|} 
Under \\
$1 \mathrm{yr}$ \\
\end{tabular} & $1-4$ & $5-14$ & $\begin{array}{c}15 \\
\text { above }\end{array}$ & $\begin{array}{c}\text { Under } \\
1 \mathrm{yr} \\
\end{array}$ & $1-4$ & $5-14$ & $\begin{array}{c}15 \\
\text { above }\end{array}$ \\
\hline 503 & 473 & 371 & 402 & 586 & 459 & 233 & 253 & 502 & 488 & 488 & 476 & 233 & 551 & 374 & 319 \\
\hline \multicolumn{4}{|c|}{1749} & \multicolumn{4}{|c|}{1531} & \multicolumn{4}{|c|}{1954} & \multicolumn{4}{|c|}{1677} \\
\hline
\end{tabular}

Table 2: Number of cases of cholera

\begin{tabular}{|c|c|c|c|c|c|c|c|c|c|c|c|c|c|c|c|}
\hline \multicolumn{3}{|c|}{ January } & \multicolumn{3}{c|}{ February } & \multicolumn{3}{c|}{ March } & \multicolumn{3}{c|}{ April } \\
\hline $\begin{array}{c}\text { Under } \\
1 y r\end{array}$ & $1-4$ & $5-14$ & $\begin{array}{c}15 \\
\text { above }\end{array}$ & $\begin{array}{c}\text { Under } \\
1 \mathrm{yr}\end{array}$ & $1-4$ & $5-14$ & $\begin{array}{c}15 \\
\text { above }\end{array}$ & $\begin{array}{c}\text { Under } \\
1 \mathrm{yr}\end{array}$ & $1-4$ & $5-14$ & $\begin{array}{c}15 \\
\text { above }\end{array}$ & $\begin{array}{c}\text { Under } \\
1 \mathrm{yr}\end{array}$ & $1-4$ & $5-14$ & $\begin{array}{c}15 \\
\text { above }\end{array}$ \\
\hline 16 & 28 & 44 & 57 & 17 & 13 & 32 & 42 & 24 & 31 & 31 & 35 & 45 & 42 & 40 & 45 \\
\hline \multicolumn{3}{|c|}{144} & & \multicolumn{3}{|c|}{104} & \multicolumn{3}{c|}{121} & & \multicolumn{3}{c|}{172} \\
\hline
\end{tabular}

In view of the various data collected on sources of environment hazards effects and control from Primary Health Care department and environment department through oral interview method. The following points could be drawn from the study area.

The respondents' show that most of the houses in the area without toilet they are dumping their excreta direct into open places. Investigation indicates that people do not dispose their waste in a proper ways. Also, there is no adequate supply of water importantly during the dry season, which makes people drink contaminated water, which lead to diseases like typhoid and cholera.

There were poor and inadequate system of refuse disposition in the area. The people in the area have negative attitude towards environmental hazard. But cooperation to make the environment tidy is not enough because people do not respond to operation keep the town clean.

Thus so far, this paper has been able to examine the environmental. The associated hazards and the potential risk to wealth. It is very clear that all human beings experience to day, ranging from communicable to Non-co experience to day, ranging from communicable to non-communicable diseases to trauma are all direct or indirect result of the filthy environment. This further confirms the importance of the environment towards the survival of man, animal and plants.

However, it is of interest to not that there are various environment laws as promulgated in Nigeria but be need to ask ourselves as to what extent these have been implemented. All hand must be on deck to make our environment conducive to health and the greater challenge is for the public health nurse inclusive. It is unfortunate to note that public health nursing is no longer what is used to be as the impact community is hardly felt. The public health nurses assisted by environment health officers are found in the community the days and this has contributed in no small measure to the increasing menace (e.g. heaps of refuse, poor drainage etc.). This is the time to act make positive change so that, life will be meaningful to all human beings.

The following recommendations were made based on the data collected and gathered; A proper sewage disposal system should be made in the town artery houses should have toilet and public toilet should be provided in market places and other places people lives. People should be educated on how to dispose refuse in proper way Government should try to provide enough dustbins of collection of refuse and also provide incinerator for proper 
burning of the refuse. The public water system available should be improved to cover the whole town especially during dry season. Government should be provide enough sanitary inspectors who will see to the supervision of the environment food vendors, water supply etc. Health education should be given to the people for free.

\section{REFERENCES}

Ajani, S.R. (1987). Quantitative Methods in the Review of Epidemiologic Literature. Epidemiologic Review 9: 1-30

Brooks S. M. and N. A. Book (1979) Tunners personal and Community Healths. Published by C. V. Mosby Company London Fifteen Editions Pgs 3-23.

Daniel F. (1941) General Science of Tropical School Book III Health Science Published by Oxford University Press pg 36-76

Meyer, P.B., and K.R. Yount. 1994. "Under investment in the Face of Environmental Risks: Cultural and Organizational Constraints to Urban Brownfield Redevelopment." Paper at the Association for Evolutionary Economics meetings, Paris, France, July.

Meyer, P.B., R.H. Williams, and K.R. Yount. 1995. Contaminated Land: Reclamation, Redevelopment and Re-Use in the United States and the European Union. Cheltenham, UK: Edward Elgar Publishing, Ltd., forthcoming.

Oyo State Environmental Protection Agency, Know your environment challenges of solid waste Management, Serial No. 100

Oyo State Environmental Protection Agency, Know your environment Environmental pollution, Serial No 005

Principles and Practice of Public Health in Africa Volume 1 Edited by G. O. Sofoluwe 12 Schram D. A. Ogunmeka, Environmental Press Plc 1996.

Rahimi G, Isachenko E, Sauer H, Isachenko V, Wartenberg M, Hescheler J, Mallmann P, Nawroth F. Effect of different vitrification protocols for human ovarian tissue on reactive oxygen species and apoptosis, Reprod Fertil Dev, 2003, vol. 15 (pg. 343-349) https:/ / doi.org/10.1071/RD02063

Roberts M.B.V (1971): Biology A Functional Approach Published by Butter and Trainer Ltd. Second Edition pg 250-260

Sofoluwe, G. O.; Adegbola, A. and Akinyanju, P. A. 1971 “Urinary delta-aminolevulinic acid. Determinations among workers charging lead accumulator batteries in Lagos, Nigeria," Archives of Environmental Health, vol. 23, no. 1, pp. 18-22.

Turner C. E. School Health and Health Education $7^{\text {th }}$ Edition C. V. Mosby Co. 1976.

World Health Orgnisation WHO International Journal of Health Development (1982) Vol. 3, N. I. General page 5.

Yount, K.R., and P.B. Meyer. 1994. "Who Will Pay for Reclamation of Urban Environmental Blight? Cultural Values, Political Beliefs, and Risk Perceptions." Paper presented at Urban Affairs Association, New Orleans, March. 